\title{
THE PROSPECTS OF DEVELOPING ENOTOURISM IN CRIMEA ON THE EXAMPLE OF THE SEVASTOPOL WINE ROAD
}

\author{
Marina V. Potanina \\ Sevastopol State University, Sevastopol, Russian Federation \\ Natalia A. Fateeva \\ Sevastopol State University, Sevastopol, Russian Federation
}

\begin{abstract}
In accordance with the development Strategy of Sevastopol and "Developing Culture and Tourism of the City of Sevastopol for 2017-2020" state program, the city of Sevastopol plans to position itself as a center of tourism. This paper discusses the possibility of developing a unique investment project in the city of Sevastopol "Wine Road. Sevastopol", analyzes the prospects of enotourism in Crimea on the example of this project. The aim of this project is to form the "Wine Road. Sevastopol" single brand, which will combine the products and services of a number of enterprises of viticulture and winemaking, including proprietor's wine. It will combine using the services of hotels, catering, production of souvenirs, etc. The city of Sevastopol has the potential to conduct wine tours, as it is able not only to satisfy the request of "rural" wine tourism, but also provide visits to the largest and most famous wineries of the city: "Inkerman", "Zolotaya Balka", Sevastopol Winery. All these objects of winemaking are located close to each other, which allows to create a large catalog of route maps to attract more tourists. According to the results of the research, the authors present a detailed SWOT analysis of the "Wine Road. Sevastopol" project, and outline the prospects of its development, future prospects, and analyze the anticipated effect of the project implementation. In case of successful implementation of this unique investment project a favorable investment climate and business environment will be formed in the city of Sevastopol. This will contribute to the increase of tourist attractiveness and investment potential of the city, improve the standard of living of citizens, increase the number of jobs.
\end{abstract}

Key words: enotourism, wine tourism, Crimea, Sevastopol Wine road, SWOT-analysis.

Citation. Potanina M.V., Fateeva N.A. The Prospects of Developing Enotourism in Crimea on the Example of the Sevastopol Wine Road. Vestnik Volgogradskogo gosudarstvennogo universiteta. Seriya 3, Ekonomika. Ekologiya [Science Journal of Volgograd State University. Global Economic System], 2019, vol. 21, no. 2, pp. 55-64. (in Russian). DOI: https://doi.org/10.15688/jvolsu3.2019.2.5

\section{ПЕРСПЕКТИВЫ РАЗВИТИЯ ЭНОТУРИЗМА В КРЫМУ НА ПРИМЕРЕ ВИННОЙ ДОРОГИ СЕВАСТОПОЛЯ}

\author{
Марина Викторовна Потанина \\ Севастопольский государственный университет, г. Севастополь, Российская Федерация \\ Наталья Алексеевна Фатеева \\ Севастопольский государственный университет, г. Севастополь, Российская Федерация
}

Аннотация. В соответствии со Стратегией развития Севастополя и государственной программой «Развитие культуры и туризма города Севастополя на 2017-2020 годы» город Севастополь планирует позиционировать себя как центр туризма. В данной работе рассматривается возможность разработки 
уникального инвестиционного проекта в городе - «Винная дорога. Севастополь», анализируются перспективы развития энотуризма в Крыму на примере этого проекта. Целью данного проекта является формирование единого бренда «Винная дорога. Севастополь», который объединит в себе продукцию и услуги ряда предприятий виноградарства и виноделия, в том числе и авторского, параллельно используя услуги гостиниц, предприятий общественного питания, производства сувенирной продукции и др. Город Севастополь имеет потенциальную возможность к проведению винных туров, так как способен не только удовлетворить запрос на «сельский» винный туризм, но и на посещение крупнейших и известнейших винзаводов города - «Инкерман», «Золотая Балка», Севастопольский винзавод. Все эти объекты виноделия расположены недалеко друг от друга, что позволяет создать большой каталог маршрутных карт для привлечения большего числа туристов. По результатам проведенных в работе исследований представлен подробный SWOT-анализ проекта «Винная дорога. Севастополь», намечены направления его совершенствования, дальнейшие перспективы, проанализирован ожидаемый эффект от внедрения проекта. В случае успеха данного уникального инвестиционного проекта в городе Севастополе будут сформированы благоприятный инвестиционный климат и деловая среда, способствующие повышению туристической привлекательности и инвестиционного потенциала города, повышению уровня жизни граждан, увеличению количества рабочих мест.

Ключевые слова: энотуризм, винный туризм, Крым, Винная дорога Севастополя, SWOT-анализ.

Цитирование. Потанина М. В., Фатеева Н. А. Перспективы развития энотуризма в Крыму на примере Винной дороги Севастополя // Вестник Волгоградского государственного университета. Серия 3, Экономика. Экология. - 2019. - Т. 21, № 2. - C. 55-64. - DOI: https://doi.org/10.15688/jvolsu3.2019.2.5

\section{Постановка проблемы}

В соответствии со Стратегией развития Севастополя и государственной программой «Развитие культуры и туризма города Севастополя на 2017-2020 годы» город Севастополь будет позиционировать себя как центр туризма. Предполагается формирование международного туристического бренда города Севастополя. Одним из пунктов стратегии развития планируется создание центра виноградарства и виноделия, который подразумевает, в том числе, и открытие винного маршрута, проходящего по Крымскому полуострову с конечным пунктом в городе Севастополе. Направление и протяженность такого маршрута напрямую зависит от расположения винных хозяйств, предприятий города Севастополя и от трассы «Таврида», которая пролегает через весь полуостров и заканчивается в Севастополе [Об утверждении Государственной программы ...].

\section{Анализ последних исследований}

Во многих странах виноделие идет параллельно с туризмом по так называемым винным путям - маршрутам, пролегающим через выдающиеся винодельческие регионы и хозяйства. Эти пути опоясывают не только всю Европу, но и вырвались далеко за ее пре- делы. Европейские винные дороги начинаются от берегов солнечной Франции, пролегают через виноградники Германии к винодельческой Италии. Всем известна Винная дорога Эльзаса - Франция, Алентежу - Португалия, Санторини - Греция, Долина Мозеля - Германия, Тоскана - Италия. Развитие винного туризма, или энотуризм ${ }^{1}$, благотворно сказывается на экономике страны, о чем свидетельствуют следующие факторы. Бордо - винная столица (только в Россию ежегодно экспортируется 3 млн бутылок одноименного вина) и один из самых интересных городов Франции - недавно включен в список Всемирного наследия ЮНЕСКО. В городе множество памятников различных эпох (Римской, Средневековья, XVIII в.), очень интересная современная архитектура. Бордо располагается на побережье Атлантики в 3 часах езды на поезде от Парижа. Air France выполняет 20 рейсов в день по маршруту Париж - Бордо. Раз в два года в июне в Бордо проводится винный фестиваль, во время которого весь центр города превращается в огромную дегустационную площадку. Ежегодно на фестивале бывает до 475 тыс. посетителей [Винный туризм Франции].

Сегодня винный туризм как хобби привлекает внимание все большего количества людей и в нашей стране. На Кубани винные туристы делают выбор, опираясь на собствен- 
ные предпочтения, путешествуя по местным винодельням, которые расположены на территории начиная от Темрюка и Таманского полуострова и заканчивая Геленджиком.

Проект «Долина Лефкадия», месторасположение - Краснодарский край, был открыт в 2004 году. За 14 лет функционирования полностью была переоборудована почти дикая территория, построены современная винодельня и лаборатория, были привлечены ведущие винные эксперты и энологи, выпущено несколько фирменных линеек вина. В 2014 г. к проекту был присоединен легендарный винный завод «Саук-Дере», в подвалах которого при идеальной постоянной температуре и влажности хранится самая большая в России коллекция вин и коньяков. Окрестности Новороссийска богаты виноградниками, там существует так называемое гаражное виноделие, то есть авторские постройки, объединяющие в себя винодельню, небольшую гостиницу и ресторан с кубанской кухней. Дегустационный зал «Абрау-Дюрсо» расположен в винных погребах завода на глубине 45 м под землей, и туристы могут стать свидетелями уникального процесса создания шампанского.

В Ставропольском крае находится хозяйство «Прасковейское», которое гордится своим музеем вин, коллекция вин собирается еще полвека назад. Также для гостей презентуют не только винное производство, но и настоящий цех выдержки спиртов, где в огромных дубовых бочках «взрослеют» коньяки.

В Тамани винодельня «Фанагория» дегустацию вин и прогулку по винограднику дополняет экскурсией в собственный гончарный цех и на бондарное производство, где вручную изготавливают бочки.

В настоящее время туризм, как и вся туристская сфера, - это огромная и быстро развивающаяся отрасль российской экономики. Если сравнивать по уровню прибыли туристскую отрасль с другими отраслями экономики, то она по прибыльность уступает только автостроению и добычи полезных ископаемых, таких как нефть и газ. Предоставление туристических услуг всегда находится в непрерывном развитии, и это качество имеет огромное значение для экономики.

С 2014 г., с момента присоединения Республики Крым и города Севастополя к Рос- сийской Федерации, огромную роль стали играть туристские центры и местные курорты. Помимо санаторно-курортной отрасли, привлекательной для развития туризма в Крыму является отрасль виноделия. Крым издревле славится своими виноградниками и винодельческой промышленностью.

В последующий период по сравнению с 2014 г. турпоток постепенно рос. Число туристов, которые посетили Севастополь в 2015 г., по сравнению с 2014 г. выросло на 40 \%, этому способствовали многочисленные исторические памятники, климат региона и культурно-массовые мероприятия. Поток туристов в 2016 г. увеличился по сравнению с 2015 г. на 46 \% благодаря проведению культурно-массовых мероприятий на Федюхиных высотах, фестиваля виноделия «Золотая Балка». 2017 год стал годом больших перемен в благоустройстве города, улиц, транспортной системы, придомовых территорий, были оборудованы новые парки, зоны отдыха, зоны для занятия спортом - такие мероприятия привели к увеличению числа отдыхающих на $47,88 \%$ (см. рис. 1 ).

С каждым годом растет количество посетителей и гостей Крымского полуострова. 2018 год был знаменателен открытием Крымского моста, данное мероприятие повлекло резкое увеличение числа туристов. Для учета результатов сезона 2018 г. представим турпоток с 2014 по 2018 г. по полугодиям. В связи с этим 2018 г. будет представлен первым полугодием на рисунке 2. Средний темп прироста за полугодие составил за период анализа $11 \%$ в полугодие [Данные о количестве туристов ...].

Исходя из этого, можно сделать вывод, что к существующим на территории туристическим маршрутам можно добавить и такой маршрут, как путешествие по Крыму с целью дегустации вин - «Винная дорога». Этот маршрут будет пролегать как по уже известным винодельческим фирмам, получившим призвание в России и за рубежом, так и по небольшим фирмам, хозяева которых знают толк в хорошем вине. Инициаторами проекта выступают небольшие винодельческие хозяйства, предлагающие авторские вина, которые имеют эксклюзивный характер. 


\section{РЕГИОНАЛЬНАЯ ЭКОНОМИКА}

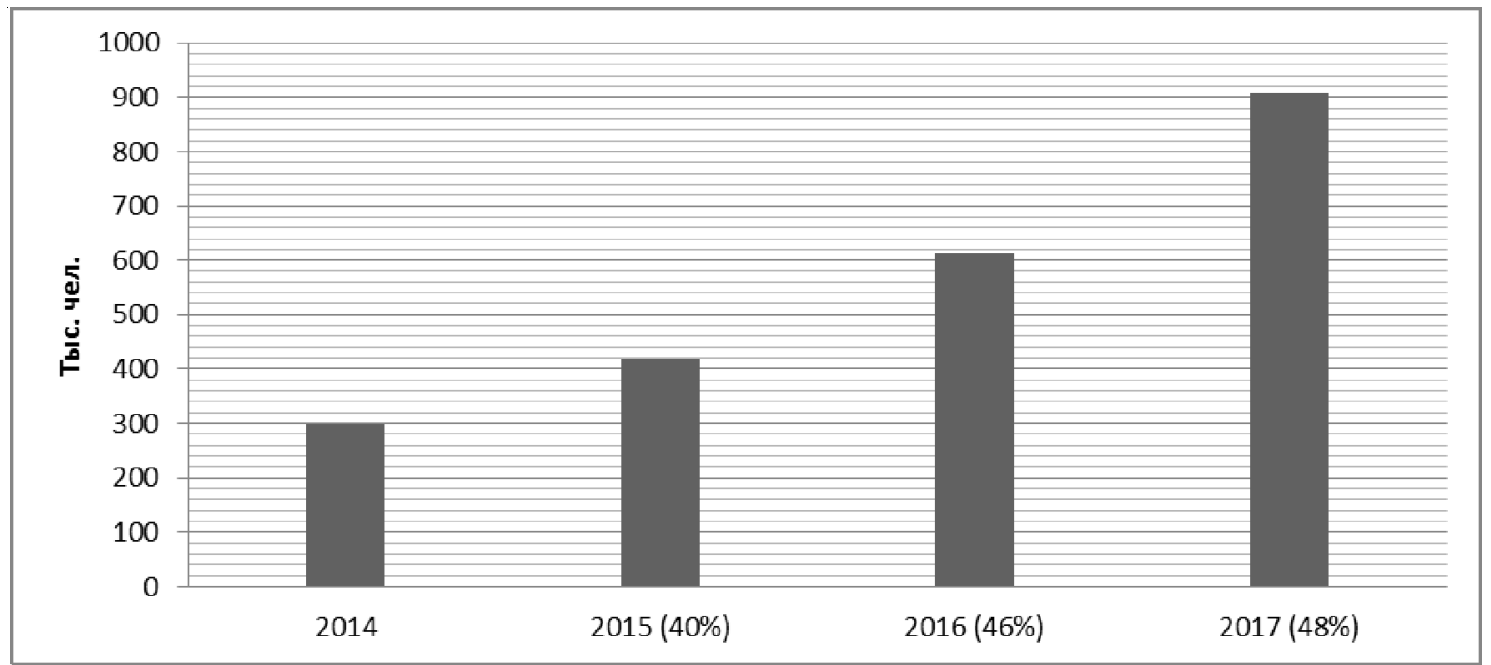

Рис. 1. Увеличение турпотока в г. Севастополе

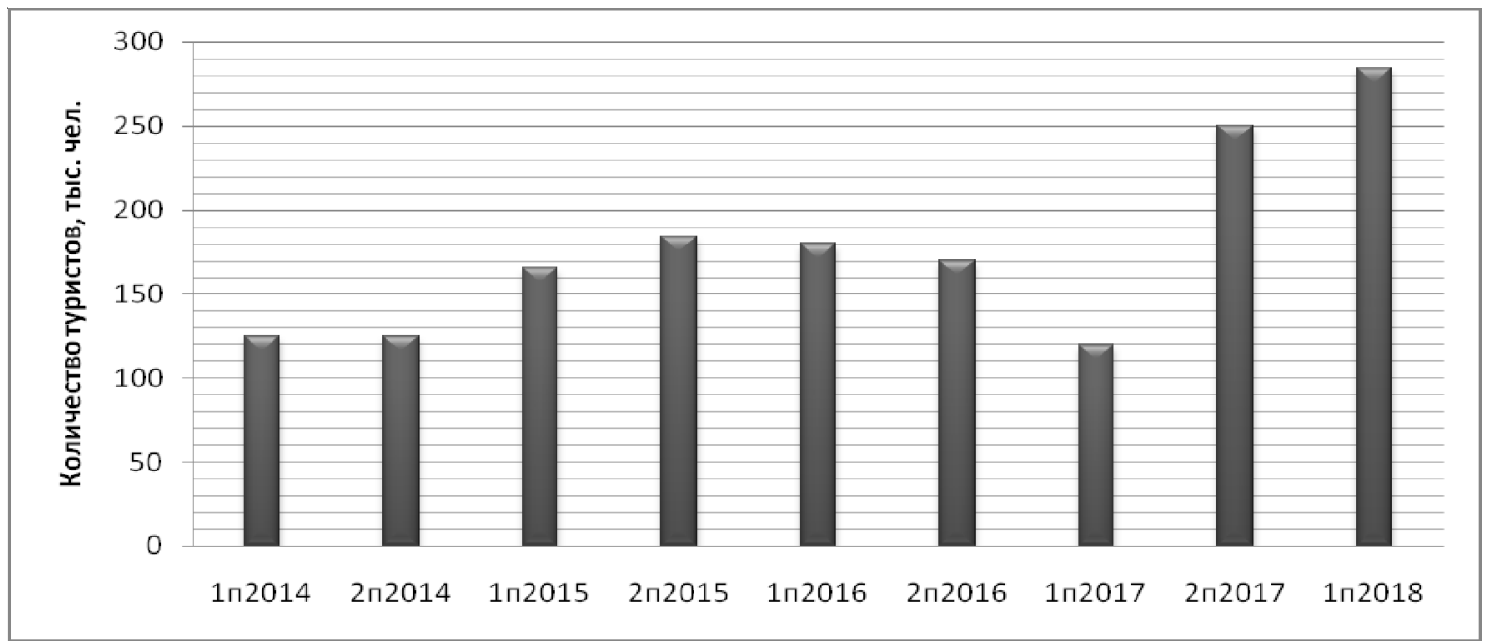

Рис. 2. Динамика турпотока по полугодиям в г. Севастополе с первого полугодия 2014 по первое полугодие 2018 г.

\section{Цель статьи}

Исследование и анализ перспектив развития энотуризма в Крыму на примере Винной дороги Севастополя.

\section{Изложение основного материала исследования}

Целью проекта является формирование единого бренда «Винная дорога. Севастополь» как объекта туризма, который объединит в себе продукцию и услуги ряда предприятий виноградарства и виноделия, параллельно используя услуги гостиниц, предприятий общественного питания, производства сувенирной продукции и др.
Город Севастополь располагает к проведению винных туров, поскольку потенциал города способен удовлетворить как запрос на «сельский» винный туризм - пребывание на природе, в сельской местности, посещение небольших частных виноделен, так и на посещения крупнейших винзаводов, которые на протяжении многих лет пользуются своей известностью, имеют богатую историю, - «Инкерман», «Золотая Балка», Севастопольский винзавод. Объекты расположены на незначительном расстоянии друг от друга, что позволяет создавать большой ассортимент маршрутных карт. Винный маршрут по городу Севастополю представлен на рисунке 3. Главные объекты Винной дороги Севастополя приведены в таблице 1 . 


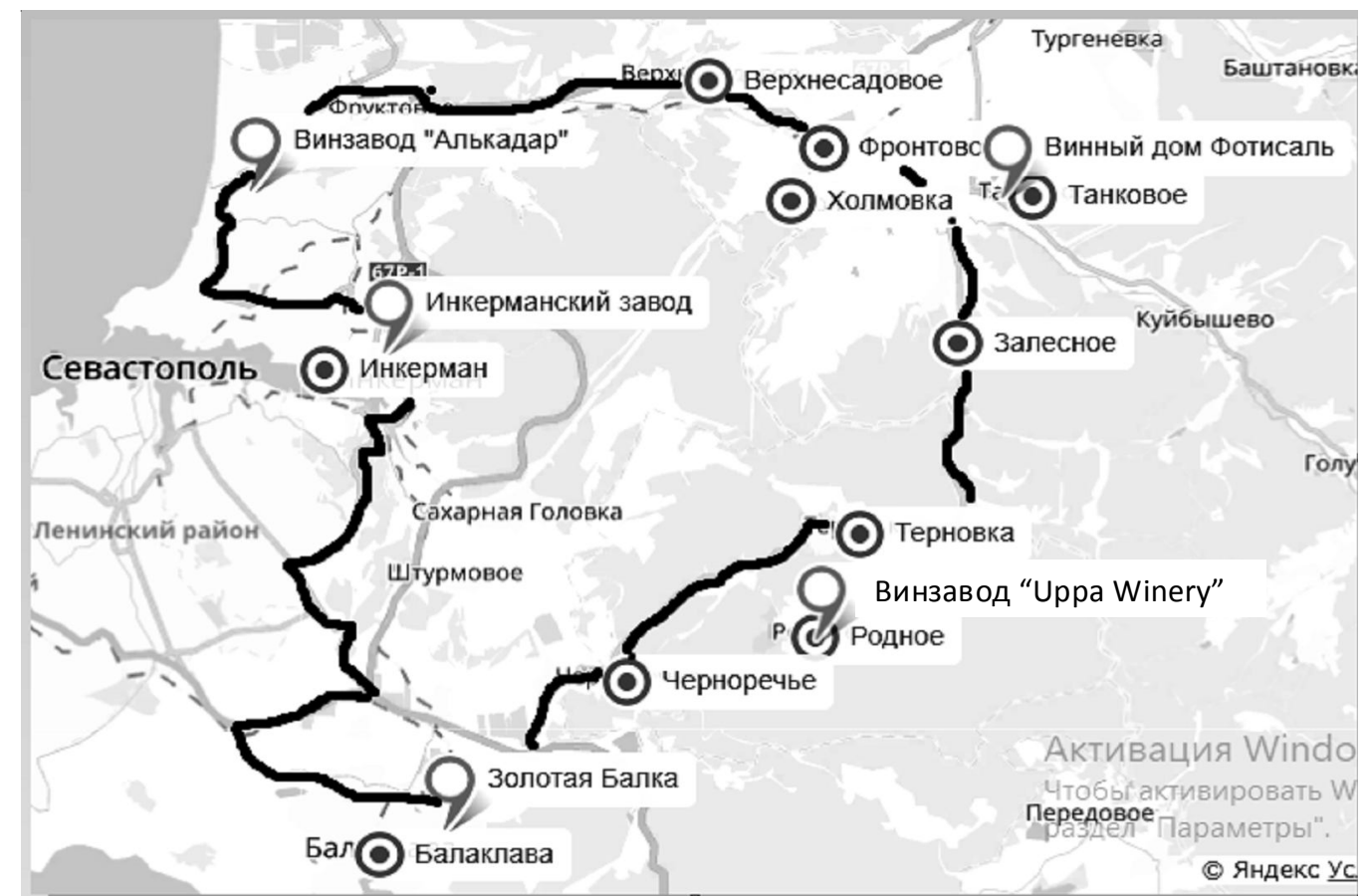

Рис. 3. Маршрут «Винная дорога Севастополя»

Таблица 1

\section{Основные объекты Винной дороги Севастополя}

\begin{tabular}{|c|c|}
\hline Объект & Описание \\
\hline $\begin{array}{l}\text { Шампанерия } \\
\text { «Золотая Бал- } \\
\text { ка» }\end{array}$ & $\begin{array}{l}\text { Шампанерия - современное здание уникальной архитектуры с дегустационным залом, ба- } \\
\text { ром, просторным магазином и крышей, оборудованной под концертные программы. Здесь } \\
\text { проводят мероприятия, объединяющие различные направления искусства - от музыки до } \\
\text { поэзии и моды, с гастрономией и виноделием. Специализация «Золотой Балки»- игристые } \\
\text { вина. Дегустируют } 6 \text { образцов, из которых } 3 \text { вида - вино }\end{array}$ \\
\hline $\begin{array}{l}\text { Винзавод } \\
\text { «Uрра Winery» }\end{array}$ & $\begin{array}{l}\text { Uppa Winery - единственная винодельня России, которая производит биодинамическое ви- } \\
\text { но. B хозяйстве Upра Winery около } 10 \text { га виноградников и годовой объем производства } \\
\text { около } 50000 \text { бутылок. Выращивается } 12 \text { сортов винограда, создается более } 20 \text { видов раз- } \\
\text { личных вин. При небольшом объеме производства вина представлены почти во всех лучших } \\
\text { ресторанах страны, украшают погреба многих коллекционеров, а также высоко ценятся ве- } \\
\text { дущими мировыми экспертами и сомелье }\end{array}$ \\
\hline $\begin{array}{l}\text { Завод «Алька- } \\
\text { дар» }\end{array}$ & $\begin{array}{l}\text { В пос. Любимовка находится известное севастопольское предприятие первичного виноде- } \\
\text { лия - ЗАО имени Софьи Перовской. Входящий в его состав винзавод «Алькадар» проводит } \\
\text { экскурсии и дегустации. Продукцию предприятия можно приобрести в фирменном магазине }\end{array}$ \\
\hline $\begin{array}{l}\text { Инкерманский } \\
\text { винзавод }\end{array}$ & $\begin{array}{l}\text { Инкерманский завод марочных вин был создан в } 1961 \text { г. на базе подземных выработок } \\
\text { строительного камня - мшанкового известняка, использовавшегося для послевоенного вос- } \\
\text { становления и строительства города Севастополя. Вина TM INKERMAN отличаются высо- } \\
\text { ким качеством, изысканным благородным вкусом и сложным неповторимым букетом. } \\
\text { За всю свою историю они получили } 13 \text { кубков Гран-при, } 142 \text { золотых, } 50 \text { серебряных и } \\
13 \text { бронзовых медалей международных конкурсов }\end{array}$ \\
\hline $\begin{array}{l}\text { Винный дом } \\
\text { «Фотисаль» }\end{array}$ & $\begin{array}{l}\text { Наличие собственных виноградников позволяет контролировать процесс рождения вина } \\
\text { с самого начала. Кроме молодых лоз, имеются и лозы, возраст которых более } 20 \text { лет. } \\
\text { Весь завод (площадь которого составляет } 5378,3 \text { кв. м.) прошел полное переоснащение и } \\
\text { имеет суперсовременное оборудование французской фирмы «Тесhnіbag», болгарской } \\
\text { «VELO», итальянской «I.B.T.» и др. На всех этапах производства происходит лабораторный, } \\
\text { органолептический и сравнительный анализ каждой партии вина }\end{array}$ \\
\hline $\begin{array}{l}\text { Севастопольс- } \\
\text { кий винзавод }\end{array}$ & $\begin{array}{l}\text { Создан в } 1960 \text { году. Выпускает уникальные игристые вина. Предприятие располагает большим } \\
\text { хранилищем с оптимальными естественными условиями хранения }+13 . .+16{ }^{\circ} \text { С (штольни). Ос- } \\
\text { новная часть торговых марок, технологий, промышленных образцов запатентована (то есть } \\
\text { имеет статус интеллектуальной собственности предприятия). Разработаны ноу-хау в вопросах } \\
\text { применения технологических приемов и микробиологических вопросах производства. Среди } \\
\text { наград продукции завода два кубка Гран-при, Золотой кубок качества и достижений маркетин- } \\
\text { га, врученный в Женеве (Швейцария), более } 40 \text { золотых, серебряных и бронзовых медалей ме- } \\
\text { ждународных конкурсов вин в Монреале, Софии, Тбилиси, Санкт-Петербурге, Одессе, Ялте }\end{array}$ \\
\hline
\end{tabular}


Для того чтобы сделать вывод о том, как будет развиваться энотуризм в городе Севастополь, был проведен SWOT-анализ. Данный вид анализа характеризуется как один из наиболее перспективных методов анализа при разработке и контроле выполнения бизнес-планов. Задачей SWOT-анализа в качестве внутреннего инструмента принятия решений для организации, работающей на рынке с плотной конкуренцией, является выявление проблемных полей по сравнению с конкурентами, а также возможностей и угроз внешней среды.

Анализ сильных и слабых сторон проекта «Винная дорога. Севастополь» - важный инструмент в принятии управленческих решений и анализе рассматриваемого маршрута, а также в оценке угроз проекта и возможностей усовершенствования и расширения предложенных услуг, повышающих привлекательность проекта как для местных жителей, так и для зарубежных гостей.

Краткий SWOT-анализ проекта «Винная дорога. Севастополь» представлен в таблице 2.

Рассмотрим подробнее результаты проведенного SWOT-анализа проекта «Винная дорога. Севастополь».

Сильные стороны энотуризма:

1. Субсредиземноморский климат: климат Крымского полуострова в сочетании с уни- кальной природой позволяет отдыхать большую часть года на территории полуострова, что ведет к обеспечению большего количества клиентов. Также почвы Крыма и Севастополя богаты природными ископаемыми - кальцием, алюминием, железом, которые идеально подходят для возделывания винограда.

2. Наличие крупных винодельческих предприятий (Севастопольский винзавод, «Золотая Балка», Инкерманский завод марочных вин, Усадьба Перовских и др.): данный фактор отражает успешное функционирование винных компаний на протяжении многих лет.

3. Авторское виноделие - это смесь науки и искусства, которые на выходе дают действительно высококачественный эксклюзивный продукт. Для изготовления авторских вин необходимы винодельня, специализированное оборудование, дубовые бочки, качественный виноград, биохимические препараты. Вина изготавливаются с использованием традиционных технологий с некоторыми нюансами, зависящими от винограда. Такие вина высоко ценятся винными экспертами и имеют высокую стоимость. «Для развития авторского виноделия в регионе будет разработана программа поддержки, - отметил губернатор Севастополя Д. Овсянников. - В стратегии развития сельского хозяйства на него будет сдела-

Таблийа 2

\section{SWOT-анализ проекта «Винная дорога. Севастополь»}

\begin{tabular}{|c|c|}
\hline Сильные стороны: & Слабые стороны: \\
\hline $\begin{array}{l}\text { - субсредиземноморский климат, уникальная природа; } \\
\text { - наличие крупных, хорошо известных винодельческих } \\
\text { предприятий с широким ассортиментом качественной } \\
\text { продукции; } \\
\text { - свободная экономическая зона на территории Респуб- } \\
\text { лики Крым и города Севастополя; } \\
\text { - авторское виноделие; } \\
\text { - наличие крупного культурно-исторического наследия } \\
\text { региона; } \\
\text { - налаженная система контроля качества, гибкие цены }\end{array}$ & $\begin{array}{l}\text { - международные санкции; } \\
\text { - труднодоступность региона для иностранных тури- } \\
\text { стов; } \\
\text { - сезонность; } \\
\text { - низкий уровень качества обслуживания объектов } \\
\text { туристической и санаторно-курортных сфер; } \\
\text { - недостаточная известность субъектов предпринима- } \\
\text { тельской деятельности винной и туристической от- } \\
\text { раслей }\end{array}$ \\
\hline Возможности: & Угрозы: \\
\hline $\begin{array}{l}\text { - улучшение развития инфраструктуры города Сева- } \\
\text { стополя; } \\
\text { - увеличение количества предприятий туристической } \\
\text { и винодельческой сферы; } \\
\text { - рост туристического потока; } \\
\text { - увеличение экспорта товара на материк; } \\
\text { - проведение фестивалей, ярмарок с дегустацией, } \\
\text { расширение сопутствующей продукции; } \\
\text { - привлечение инвестирования для развития вино- } \\
\text { дельческой отрасли в Крыму и Севастополе }\end{array}$ & $\begin{array}{l}\text { - зависимость от климата; } \\
\text { - снижение платежеспособности населения; } \\
\text { - ужесточение налогово-бюджетной и акцизной по- } \\
\text { литики; } \\
\text { - разрозненность малых объектов виноделия и туризма; } \\
\text { - негативное отношение людей, ведущих здоровый } \\
\text { образ жизни; } \\
\text { - ужесточение конкуренции }\end{array}$ \\
\hline
\end{tabular}


на ставка. У нас есть все необходимые природные условия, инвесторы готовы использовать современные технологии и оборудование, могут поставлять на рынок отличную конкурентоспособную винную продукцию» [Ставка Дмитрия Овсянникова ...].

4. Известность, широкий ассортимент и высокий уровень качества крымских вин на российском, а также зарубежном рынке: работая продолжительное время, предприятия получили известность на рынке с сохранением и укреплением репутации винных заводов, что позволяет удерживать постоянных клиентов и привлекать новых.

5. Рекламная поддержка крупных предприятий винодельческой отрасли: как правило, потребитель с большой осторожностью относится к новым винным продуктам, вместо них отдает предпочтения известным и «проверенным» позициям.

6. Наличие крупного культурно-исторического наследия в городе Севастополе: культурное наследие, богатый исторический потенциал, уникальная природа полуострова безграничный вклад для привлечения большого количества туристов.

7. Наличие свободной экономической зоны на территории Республики Крым и города Севастополя: Республика Крым и город Севастополь представляют собой ограниченную территорию, которая имеет свой особый статус в отношении ведения бизнеса и льготные экономические условия, в данном случае речь идет о налоговых послаблениях для предпринимателей.

8. Гибкая ценовая политика: применение грамотно разработанной ценовой политики позволит получить высокую прибыль за счет большого количества товарооборота, а не за счет высокой цены.

9. Налаженная система контроля качества: наличие системы комплексного управления качеством приводит к реализации продукции, соответствующей установленным требованиям.

Слабые стороны проекта «Винная дорога. Севастополь»:

1. Международные санкции: для Крыма и Севастополя результатом экономических санкций стало ощутимое падение уровня жизни населения, стагнация экономики и возросший уровень инфляции.
2. Труднодоступность региона: поскольку введенные экономические санкции оказывают негативное влияние на мировоззрение потенциальных туристов, многие зарубежные туристы не могут или не хотят посещать полуостров, вследствие чего снижается туристический поток.

3. Сезонность: туристические услуги, предоставляемые на полуострове, наиболее актуальны в летний период, в результате чего наблюдается резкое снижение посещаемости полуострова в осенне-зимний период.

4. Низкий уровень качества обслуживания объектов туристической и санаторно-курортной сфер: туристский регион должен иметь все необходимые сооружения для пребывания в нем туристов, низкое качество обслуживания и недостаток необходимой инфраструктуры будут непривлекательны для туристов.

5. Слабая информированность субъектов малой предпринимательской деятельности винной и туристической отраслей: необходимо уделять больше внимания рекламе соответствующих субъектов (выпуск информационных стендов об их деятельности).

Среди основных возможностей следует отметить:

1. Улучшение развития инфраструктуры Севастополя: в настоящее время правительство города Севастополя планирует повысить уровень инфраструктуры города при помощи модернизации уже имеющихся объектов, ожидается, что проект «Винная дорога. Севастополь» увеличит привлекательность региона, количество туристов [Постановление Правительства РФ от 11.08.2014 г. № 790].

2. Рост количества предприятий туристической и винодельческой сферы: внедрение винного маршрута дает перспективу открытия новых предприятий винодельческой промышленности, а также расширения сортов вин.

3. Рост туристического потока: при успешном внедрении проекта «Винная дорога. Севастополь» увеличится поток туристов, местных жителей и гостей полуострова, желающих продегустировать местные сорта вин и посетить объекты культурного наследия полуострова.

4. Смягчение налогово-бюджетной и акцизной политики для предприятий региона. По- 
скольку территории Республики Крым и города Севастополя являются свободной экономической зоной, то в настоящее время многие предприятия винодельческой и туристической отраслей могут получить налоговые льготы [Федеральный закон от 29.11.2014 г. № 377-Ф3].

5. Повышение качества знаний персонала винодельческой и туристической отраслей. Понятия «качество услуг» и «качество обслуживания» тесно связаны друг с другом, так как и то и другое зависит от производственных возможностей туристических объектов, будь то отель, пансионат либо санаторий, и чем выше уровень обслуживания туристов, тем более привлекателен становится объект. Подготовку виноделов уже осуществляют Филиал МГУ им. М.В. Ломоносова в г. Севастополе [Лаборатория вина ...], Крымский федеральный университет [Кафедра виноделия ...], с 2019 г. подготовку виноделов начнет Севастопольский государственный университет [В СевГУ ...], также во многих высших учебных заведениях Крыма уже готовят специалистов в сфере туризма.

6. Открытие музея авторского виноделия как новой достопримечательности региона будет не только привлекать большее количество туристов, но и способствовать популяризации науки о вине. Правительство Севастополя приступило к разработке программы развития авторского виноделия.

7. Разработка разных маршрутов по Винной дороге Севастополя, учитывая возраст и предпочтения посетителей. Поскольку ожидаются туристы разных возрастных категорий, личностных предпочтений и разного финансового положения, принято решение разработать несколько вариантов маршрутов для каждой категории населения, а также будет предоставлено право самим составить маршрут, предварительно согласовав с организаторами.

8. Проведение «винных» фестивалей. Фестиваль - это возможность не только продегустировать качественные вина разных производителей, но и шанс узнать новое о вине и гастрономии, а также побывать на мастеркласс-дегустациях. Владельцы баров, ресторанов, профессиональные сомелье и коллекционеры вин на подобных фестивалях имеют уникальную возможность найти партнеров по бизнесу и узнать много нового. Для профес- сионалов даже будут устраивать винные туры с посещением виноградников. Компания «Золотая Балка» в честь международного дня шампанского проводит ежегодный музыкальный фестиваль на виноградниках «\#ZBFest» и ежегодный праздник сбора урожая и виноделия «\#WineFest», в котором всего за два дня каждый сможет совершить невероятное эногастрономическое путешествие по солнечному полуострову.

9. Увеличение экспорта товара на материк. Виноделие в Севастополе существует уже более двух тысяч лет. Увеличение объемов производства, продвижение продукции на отечественном и зарубежном рынках будут способствовать большему экспорту товаров винной отрасли за пределы Крымского полуострова.

10. Привлечение инвесторов для расширения сортов винограда в Севастополе. Так как количество предпринимателей увеличивается с каждым годом, необходимо привлекать инвесторов, готовых вложить денежные средства в винодельческую отрасль. Во многом этому способствуют Ялтинский международный экономический форум и наличие свободной экономической зоны на территории полуострова.

Угрозами развития энотуризма являются следующие факторы:

1. Зависимость от климата. Климат является основополагающим фактором для выращивания винограда, который определяет его рост, развитие и плодоношение. При неблагоприятных погодных условиях ухудшается качество винограда [Климатические условия ...].

2. Снижение уровня жизни населения и его платежеспособности. При влиянии данного фактора уменьшается в структуре расходов удельный вес расходов на развлечения и отдых.

3. Рост инфляции. Изменение курса валюты приводит к увеличению затрат на производство вина и организацию энотуризма на Крымском полуострове, тем самым увеличивается цена тура.

4. Ужесточение налогово-бюджетной и акцизной политики для предприятий региона. Увеличение акцизного сбора приводит к удорожанию стоимости алкогольной продукции, увеличение налоговых ставок приводит к сокращению производителей вина [Данные по формам ... отчетности]. 
5. Негативные отзывы людей, придерживающихся здорового образа жизни (ЗОЖ). Здоровый образ жизни набирает все большую популярность с каждым годом, идет его активная пропаганда в школах, университетах, СМИ, появилась мода на ЗОЖ.

6. Разрозненность малых объектов виноделия и туризма. Так как предприятия территориально отделены друг от друга, это приводит к ограничению информации, ослаблению системы контроля бизнес-процессов, отсутствию эффекта синергии.

7. Увеличение конкуренции. На сегодняшний момент в России, в Краснодарском, Ставропольском краях и за рубежом уже успешно функционируют энотуры с высоким качеством услуг и невысокими ценами, поэтому проект «Винная дорога. Севастополь» может оказаться неконкурентоспособным по сравнению с уже имеющимися энотурами.

\section{Выводы. Перспективы дальнейших исследований}

Область энотуризма имеет огромный потенциал. К ожидаемым эффектам от данного проекта можно отнести: рост платежеспособного туристического потока, снижение его сезонности, повышение качества продукции и услуг, создание новых рабочих мест, рост налоговых отчислений, развитие инфраструктуры населенных пунктов, вошедших в маршрут, повышение узнаваемости местных производителей вина, сыров и другой сопутствующей продукции в регионах России и за рубежом. Авторское виноделие займет в данном проекте одну из лидирующих позиций. Все эти факторы также будут способствовать развитию культурно-познавательных программ энотуризма, побуждать туристов узнавать все новые его грани. Учитывая проведенный SWOT-анализ проекта, можно сделать вывод о том, что проект «Винная дорога. Севастополь» может быть успешно реализован на территории Крыма и города Севастополя в ближайшие годы.

\section{ПРИМЕЧАНИЕ}

1 Энотуризм - это разновидность туризма, целью которого является знакомство с винными традициями определенного региона. Специализи- рованные туры могут включать в себя посещение виноградников, виноделен, ресторанов, винных фестивалей и иных мероприятий.

\section{СПИСОК ЛИТЕРАТУРЫ}

В СевГУ начнут готовить виноградарей и виноделов СевГУ. - Электрон. текстовые дан. - Режим доступа: https://www.sevsu.ru/novosti/item/ 4284-v-sevgu-nachnut-gotovit-vinogradarej-ivinodelov. - Загл. с экрана.

Винный туризм Франции. - Электрон. текстовые дан. - Режим доступа: https://vuzlit.ru/356803/ vinnyy_turizm_frantsii\#897. - Загл. с экрана.

Данные о количестве туристов, посетивших Севастополь по полугодиям: 2014-2016 гг. // Письмо Заместителя руководителя Федерального агентства по туризму А.А. Конюшкова в адрес руководителя Форума СИ МБФ А.В. Малько. - Электрон. текстовые дан. - Режим доступа: http:// www.simbf.ru/images/SIMBF 2016RUS/ Resolution_1_SIMBF_2016/Russia\%20Travel \%20letter\%2029\%20Sept\%2016.pdf. - Загл. с экрана.

Данные по формам статистической налоговой отчетности. - Электрон. текстовые дан. - Режим доступа: https://www.nalog.ru/rn48/related_activities/ statistics_and_analytics/forms/.- Загл. с экрана.

Кафедра виноделия и технологии бродильных производств Крымского федерального университета имени В.И. Вернадского. - Электрон. текстовые дан. - Режим доступа: http://abip.cfuv.ru/? page_id=4243. - Загл. с экрана.

Климатические условия культуры винограда. Электрон. текстовые дан. - Режим доступа: http://wine.historic.ru/books/item/f00/s00/ z0000017/st014.shtml. - Загл. с экрана.

Лаборатория вина создана в Севастопольском филиале МГУ. - Электрон. текстовые дан. - Режим доступа: https://www.msu.ru/press/smiaboutmsu/ laboratoriya-vina-sozdana-v-sevastopolskomfiliale-mgu.html. - Загл. с экрана.

Об утверждении Государственной программы развития курортов и туризма в Республике Крым на 2017-2020 годы. - Электрон. текстовые дан. - Режим доступа: https://mtur.rk.gov.ru/ file/proekt_postanovleniya_soveta_ ministrov.pdf. - Загл. с экрана.

ПостановлениеПравительства РФ ог 11.08.2014 г. № 790 (ред. от 22.01.2018) «Об угверждении федеральной целевой программы “Социально-экономическое развитие Республики Крым и г. Севастополя до 2020 года"». - Электрон. текстовые дан. Режим доступа: http://www.garant.ru/products/ ipo/prime/doc/70614732/. - Загл. с экрана. 
Ставка Дмитрия Овсянникова на развитие авторского виноделия в Севастополе: миф или реальность. - Электрон. текстовые дан. - Режим доступа: http://sevoborona.info/stavka-dmitriyaovsyannikova-na-razvitie-avtorskogo-vinodeliyav-sevastopole-mif-ili-realnost/. - Загл. с экрана.

Федеральный закон от 29.11.2014 г. № 377-Ф3 (ред. от 29.12.2017) «О развитии Республики Крым и города федерального значения Севастополя и свободной экономической зоне на территориях Республики Крым и города федерального значения Севастополя». - Электрон. текстовые дан. - Режим доступа: http:// base.garant.ru/70807520/. - Загл. с экрана.

\section{REFERENCES}

VSevGU nachnut gotovit'vinogradarej i vinodelov. URL: https://www.sevsu.ru/novosti/item/4284-v-sevgunachnut-gotovit-vinogradarej-i-vinodelov.

Vinnyj turizm Frantsii. URL: https://vuzlit.ru/356803/ vinnyy_turizm_frantsii\#897.

Dannye o kolichestve turistov, posetivshikh Sevastopol' po polugodiyam: 2014-2016 gg. Pis'mo Zamestitelya rukovoditelya Federal'nogo agentstva po turizmu A.A. Konyushkova v adres rukovoditelya Foruma SIMBF A.V. Mal'ko, 2018. URL: http://www.simbf.ru/images/SIMBF2016RUS/ Resolution_1_SIMBF_2016/Russia\%20Travel $\%$ 20letter $\% 2029 \% 20$ Sept $\% 2016$.pdf.

Dannye po formam statisticheskoj nalogovoj otchyotnosti. URL: https://www.nalog.ru/rn48/ related_activities/statistics_and_analytics/forms/.
Kafedra vinodeliya $i$ tekhnologii brodil'nykh proizvodstv Krymskogo federal'nogo universiteta imeni V.I.Vernadskogo. URL: http://abip.cfuv.ru/ ?page_id=4243.

Klimaticheskie usloviya kul'tury vinograda. URL: http://wine.historic.ru/books/item/f00/s00/ z0000017/st014.shtml.

Laboratoriya vina sozdana v sevastopol'skom filiale $M G U$. URL: https://www.msu.ru/press/ smiaboutmsu/laboratoriya-vina-sozdana-vsevastopolskom-filiale-mgu.html.

Ob utverzhdenii Gosudarstvennoj programmy razvitiya kurortov i turizma v Respublike Krym na 20172020 gody. URL: https://mtur.rk.gov.ru/file/ proekt_postanovleniya_soveta_ministrov.pdf.

Postanovlenie Pravitel'stva RF ot $11.08 .2014 \mathrm{~g}$. No. 790 (red. ot 22.01.2018) "Ob utverzhdenii federal'noj tselevoj programmy "Sotsial'noehkonomicheskoe razvitie Respubliki Krym $i$ g. Sevastopolya do 2020 goda". URL: http:// www.garant.ru/products/ipo/prime/doc/ 70614732/.

Stavka Dmitriya Ovsyannikova na razvitie avtorskogo vinodeliya $v$ Sevastopole: mif ili real'nost'. URL: http://sevoborona.info/stavkadmitriya-ovsyannikova-na-razvitie-avtorskogovinodeliya-v-sevastopole-mif-ili-realnost/.

Federal'nyj zakon ot 29.11.2014 g. No. 377-FZ (red. ot 29.12.2017) "O razvitii Respubliki Krym $i$ goroda federal'nogo znacheniya Sevastopolya $i$ svobodnoj ehkonomicheskoj zone na territoriyakh Respubliki Krym i goroda federal 'nogo znacheniya Sevastopolya". URL: http://base.garant.ru/70807520/.

\section{Information about the Authors}

Marina V. Potanina, Candidate of Sciences (Engineering), Associate Professor, Department of Management and Business Intelligence, Sevastopol State University, Gogolya St., 14, 299011 Sevastopol, Russian Federation, mvpotanina@sevsu.ru, https://orcid.org/0000-0003-3819-0201

Natalia A. Fateeva, Master Student, Department of Management and Business Intelligence, Sevastopol State University, Gogolya St., 14, 299011 Sevastopol, Russian Federation, natalia.fateeva28@yandex.ru, https://orcid.org/0000-0002-0488-0899

\section{Информация об авторах}

Марина Викторовна Потанина, кандидат технических наук, доцент кафедры менеджмента и бизнес-аналитики, Севастопольский государственный университет, ул. Гоголя, 14, 299011 г. Севастополь, Российская Федерация, mvpotanina@sevsu.ru, https://orcid.org/0000-0003-3819-0201

Наталья Алексеевна Фатеева, магистрант кафедры менеджмента и бизнес-аналитики, Севастопольский государственный университет, ул. Гоголя, 14, 299011 г. Севастополь, Российская Федерация, natalia.fateeva28@yandex.ru, https://orcid.org/0000-0002-0488-0899 